This is a pre-copy-editing, author-produced PDF of an article accepted following peer review for publication in Nomadic Peoples, 19 (2), 281-302.

The definitive publisher-authenticated version is available online, doi: http://dx.doi.org/10.3197/np.2015.190208

\title{
LOCAL EXPERIENCES AND CONTESTED MEANINGS OF THE CHINESE 'GRAIN FOR GREEN' LAND CONVERSION PROGRAMME IN AN AGRO-PASTORALIST TIBETAN COMMUNITY
}

\section{EMILY WOODHOUSE}

Department of Anthropology

University College London

Email: e.woodhouse@ucl.ac.uk

\section{ABSTRACT}

The Sloping Land Conversion Programme (SLCP; 'Grain for Green') forms one part in a suite of programmes focused on 'ecological construction' in minority areas of Western China. It aims to increase vegetation and reduce poverty by providing payments to households for retiring agricultural and grazing land to plant trees and grass. This paper examines how SLCP is being experienced and perceived in one agro-pastoral Tibetan community in Sichuan Province on the eastern Tibetan Plateau, and focuses on livelihoods impacts, environmental sustainability, and local versus state meanings. Participants were motivated by purely financial reasons, but some, especially poorer households, were concerned about impacts on livelihoods. Respondents questioned the environmental impacts and rationale of SLCP given the low survival rates of trees and lack of incentives for longterm management. There were barriers to moving to off-farm work alongside a resistance to leaving a subsistence livelihood base and agro-pastoral lifestyle. Positive views about the policy's environmental and wellbeing benefits were reserved for plantations on unproductive land. Local responses to SLCP highlight issues with wider state-led policies that expropriate land and resources and privilege economic valuation of the environment. 


\section{KEYWORDS}

Environmental policy; livelihoods; pastoralism; payment for ecosystem services; Tibet.

\section{INTRODUCTION}

In response to catastrophic flooding on the Yangtze River in 1998, the Chinese government shifted forest policy away from timber production, towards restoring and conserving forests and vegetation in order to address soil erosion (Wang et al., 2004). With a budget of more than $\$ 40$ billion the Sloping Land Conversion Programme (SLCP; tuigeng huanlin huancao), otherwise known as 'Grain for Green', is one of the largest land-conversion programmes in the world and aims to increase vegetation on degraded farm and rangelands. Together with the Natural Forest Protection Programme (NFPP), which imposes a blanket ban on logging across many areas, the conversion of pastures to grassland (tuimu huancao), and ecological resettlement (shengtai yimin), it forms a suite of environmental policies that are profoundly influencing rural peoples, especially in Western China. These programmes have been implemented in line with China's policy to 'Open up the West' (xibu da kaifa), which aims to close economic disparities between the prosperous east coast and the Western provinces (McNally, 2004). They have several factors in common: first, the centrality of the concept of 'ecological construction', which refers to state-directed efforts to improve the environment, especially increases in vegetation (Jiang, 2006); second, the dual aims of environmental restoration and poverty alleviation through the 'modernisation' of pastoral and agricultural systems, which largely involves retiring land from productive use.

The policies mirror a global shift towards neo-liberal conservation methods, including the proliferation of 'payment for ecosystem services' (PES) projects in which the environment is brought into the market economy (Buscher, 2012). The SLCP is ostensibly a PES scheme, in which households are provided with positive incentives of grain and money on the condition that they plant and nurture trees or grass on their degraded and sloping farmland, thus providing the service of watershed protection (Wunder et al., 2008). Research on PES has moved beyond a purely technical focus on efficiency and effectiveness to highlight the significance of wider political aims, local institutions and social justice issues in shaping environmental and cultural outcomes (e.g. Corbera et 
al., 2007; Gómez-Baggethun et al., 2011). Environmental policies in western China have similarly been recognised as political projects, in which the environment is defined and produced in a particular way, legitimising the policies themselves and new forms of state control (Yeh, 2005, 2013). Given that the targeted areas coincide with minority populations, especially pastoralist groups with diverse cultural histories, there are also cultural dimensions to these planned processes of change $\mathrm{Xu}$ and Ribot, 2004).

A range of research has emphasised the technical effectiveness of the SLCP, especially overall increases in forest cover (Liu et al., 2008) and impacts on rural incomes (e.g. Li et al., 2011). Few studies have focused on local perspectives and local-level implementation, which exhibit huge variation across the vast landscape of western China (Bennett, 2008). There has been little research on the particular experiences of Tibetans, which is a significant omission given the ways - politically, economically and culturally - in which Tibetans are marginalised in China, and the rapid economic changes that are occurring in Tibet (Fischer, 2013), as well as the important but shifting socioreligious and political significance of the natural environment in Tibetan communities (Woodhouse et al., 2015; Yeh, 2014).

As participants near the end of the SLCP payments (2018, unless the policy is prolonged), I explore how this programme may be shaping relationships between people and their environment in one agropastoral Tibetan community in Daocheng County, Sichuan Province. I examine local implementation and community perspectives on the programme, and contextualise these in relation to state-led environment and development projects being implemented in minority areas of China, and broader market-based conservation approaches worldwide. The paper takes a local perspective to ask the following questions:

What are the perceived impacts of SLCP on local agro-pastoralist livelihoods and economic wellbeing?

What problems are there with implementation and the potential implications for sustainability?

How do Tibetans ascribe meaning to the processes and outcomes of the land conversion, and how does this contrast or align with state discourse?

THE ‘GRAIN FOR GREEN’ PROGRAMME 
The Sloping Land Conversion Programme (SLCP) has the stated environmental goals of reducing soil erosion, increasing China's forest cover, alleviating poverty and transitioning farming households towards 'sustainable structures of production' (Bennett, 2008). As such, it adheres to the Chinese state view that poverty alleviation and environmental improvement are mutually reinforcing; left unaddressed, poverty and environmental degradation are seen as a threat to both the economic and social stability of the nation (Yeh, 2005). The programme aimed to increase vegetative cover (forest and grass) by 32 million hectares by 2010, 14.7 million hectares of which was retired cropland on steep slopes (defined as being over 25 degrees) and the rest on barren land, or 'wasteland' (Liu et al., 2008). The result would be a ten per cent decrease in cultivated land in China. By 2008, 8 million hectares of agricultural land had been converted - less than sixty per cent of the target - but 4.2 million hectares had also been forested on other land (Yin et al., 2014). Overall, it aims to target seriously degraded land and ecologically important (but agriculturally less productive) land. The state (at the national level and in the Daocheng Forest Bureau) focuses on restoring land that was previously converted to agriculture during the 'Great Leap Forward'. The programme also has the stated aims of improving local volunteerism and autonomy (Bennett, 2008).

The programme was initially piloted in three Western provinces of China (Sichuan, Gansu and Shanxi) between 1999 and 2001, and in 2002 it was expanded to twenty-five provinces and two thousand counties, covering an ecologically, economically and culturally heterogeneous area. The focus is on the Western regions since they contain the headwaters of both the Yangtze and Yellow Rivers. The survival rate of the vegetation for compliance is seventy-five per cent, and cash payments of between 2100-3150 yuan per hectare per year are provided (US\$1 = ¥6.2 in May 2015), as well as an additional 300 yuan per hectare per year for 'miscellaneous expenses' to cover the cost of seeds and continuing care. Payments are given annually for eight years for planting what the government deems to be 'ecological' trees (timber species), five years for 'economic' trees (fruit and nut trees), and two years for grass. Subsidies of grain were initially provided to households instead of cash, but this was phased out. The programme ran until 2010, and payments will extend until 2018 unless it is extended further.

Although the scheme has increased vegetation cover and reduced surface run-off and soil erosion (Liu et al., 2008), there is concern over the social, economic and environmental effects of the programme (Cao, 2011). Overall, the programme has been presented as an environmental success at the regional level, but specific problems regarding implementation, as well as negative social and environmental 
impacts, have been reported locally. The planting of inappropriate species, especially in the arid and semi-arid regions of China (Shaanxi Province), resulted in reduced soil moisture and reduced understory growth, consequently reducing vegetation cover and diversity compared to the natural recovery in an abandoned plot (Cao et al., 2009a). Potential problems include the lack of conditionality, adaptation to local conditions, and mechanisms to ensure trees survive and are not harvested, which belie the programme's overall ecological success (Bennett, 2008).

\section{STUDY SITE}

The community of Samdo (gsum 'dus; Chinese: Sangdui) ${ }^{1}$ is located in the northern part of Daocheng (Tibetan: Dabpa; 'dab pa) County, in the Ganzi Tibetan Autonomous Prefecture, Sichuan Province (PRC) at an altitude of 3,950 m, and comprises four villages and around two hundred and twenty households. This valley community is, in fact, one of three groups of villages within Sangdui township (xiang), which incorporates ten villages. It is the most northerly of the three and holds the township government offices. It is located in the easterly Kham region of Tibet $^{2}$ on the south-eastern part of the Tibetan Plateau, where milder climatic conditions result in subalpine, cold temperate forest ecosystems. The study site is dominated by relatively flat plateaus and grasslands, and the forested valley slopes consist mainly of conifers (fir and spruce) mixed with broadleaved deciduous and evergreen species (larch and oak). The majority of rural Tibetans in this region are agro-pastoralists, with households allocating varying levels of resources between the two livelihood modes. They lead a semi-nomadic lifestyle characterised by seasonal vertical shifts to grazing land, combined with farming in permanent settlements located in the valley, where they grow grain (barley) and a small number of vegetables for household use and trade. Since economic liberalisation in the early 1980s, demand by Chinese consumers for the parasitic medicinal caterpillar fungus (Ophiocordyceps sinensis) has fuelled a rapid transition to a cash economy in areas of the Plateau where the fungus grows (Winkler, 2008). In 2009, an average of seventy-two per cent of household cash income in Samdo came from selling the fungus (Woodhouse et al., 2014). The mean average household annual income was 6,639 yuan (median $=5,500$, ranging from 850 to 20,000 yuan; $\mathrm{n}=50$ ). Samdo is located in the west of Sichuan Province, an area recognised for its high level of biodiversity and endemism (Conservation International, 2012). The forested uplands provide vitally important watershed protection, preventing soil erosion, but have suffered deforestation and degradation during the last

\footnotetext{
${ }^{1}$ Tibetan words are given phonetically as they are pronounced locally, with Wylie transliteration provided.

${ }^{2}$ Tibet refers to all Tibetan areas of the People's Republic of China including the Tibetan Autonomous Region, and areas of Qinghai, Gansu, Sichuan and Yunnan. The administrative divisions which are identified as Tibetan autonomous areas (prefectures and counties, plus TAR) broadly conform to what is now considered to be Tibet by Tibetans and the Tibetan Government in Exile.
} 
century (Harkness, 1998). It is estimated that forest cover has decreased in Western Sichuan from thirty per cent in the 1950s to fourteen per cent in the 1980s (Li, 1993). During Mao Zedong's 'Great Leap Forward' of 1958 to 1960, felled forests fuelled furnaces in a failed attempt to boost steel production (Shapiro, 2001). In western Sichuan, timber logging was the primary economic sector for development (Winkler, 2003) and in Daocheng there were seven commercial forestry sites accounting for fifty to sixty per cent of Provincial revenues, until logging restrictions were implemented in the mid-1990s.

\section{METHODS}

A combination of household, key-informant interviews and participant observation was used during fieldwork. Semi-structured household interviews were carried out in Samdo during January to April 2010. Based on preliminary research and that of others in Tibetan communities (e.g. Mills, 2003), the household is taken as the unit of economic activity including natural-resource use as well as ritual practice. Given the focus on natural-resource use and especially household involvement in SLCP, it was appropriate to sample at this level for semi-structured interviews. ${ }^{3}$ Interviews were conducted with the household head and/or other people involved in household decision-making. ${ }^{4}$ The average age of the primary respondent was forty-eight years, ranging from thirty to sixty-six years. Interviews were primarily carried out with men, but in ten out of fifty cases women (mainly wives) were present and contributed to the interview, and in nine cases women were the primary respondents. Women were also interviewed separately as key informants.

I selected households by numbering all the houses in the valley, drew a random number, and then visited the corresponding house. The interviews aimed to obtain information on household resource use, livelihoods, and involvement in, as well as perspectives on, environmental policies. Open-ended questions provided flexibility during discussions. To incorporate local ideas of wealth, which may differ significantly from Western ideas and income-based indices, key informants drew up a list of

\footnotetext{
${ }^{3}$ A household in Samdo is based on a family unit of head male, wife, children and grandparents; and sometimes cousins, aunts and uncles. Descriptions of Tibetan society discuss the household in terms of estates separated into two houses - one 'small' (khang-chung) where elderly grandparents live, and the other 'big' (khang-chen) where married couples and their children live. One household interviewed had this type of structure, in which case I treated the 'estate' as one economic household; but this type of household was not common in Samdo and households were usually aligned with houses.

${ }^{4}$ This was normally a man. The household head was not always a clearly defined role in many households, as there was a fluid transition from generation to generation. If the respondent was not able to answer questions, we returned to meet with a different member of the household later.
} 
locally relevant indicators of wealth such as house size, presence of a shrine room, ownership of a motorbike and number of livestock, which were used as indicators of wealth. Based on these indicators, households were categorised into three wealth categories: poor $(n=11)$, middle $(n=26)$ and wealthy $(\mathrm{n}=13)$.

The questions were piloted in six households in a neighbouring valley and then fifty interviews were conducted in Samdo, one in each household sampled, representing twenty-three per cent of the households in the valley. Interviews were carried out in the respondents' homes in the Kham Tibetan dialect with help from a translator, recorded in agreement with the participants, and translated into English. During the period of field work (May to June 2009; January to April, then August to December 2010), I gained further knowledge through discussions with key informants with particular knowledge and expertise (e.g., government workers at the village and county level, elders and village leaders). Living in the valley also provided opportunities to observe everyday situations and allowed for contextualisation of the interview data. Qualitative interview data were stored, managed and coded using NVivo (QSR International, 2010). ${ }^{5}$

\section{RESULTS}

Local implementation of 'Grain for Green'

SLCP is conducted using a top-down approach, whereby quotas are set by the provincial government, which then allocates quotas to county offices of the Forest Bureau, and then townships and villages. For Samdo, tree survival rate for compliance is seventy-five per cent, and cash subsidies are set at 3,150 yuan per hectare per year for eight years. From 2009, compensation rose to 3,600 yuan. Poplar (Populus schneider) and spruce (Picea balfouriana) have been planted in roughly equal proportions in Samdo. The Forest Bureau reported that poplar had been chosen by the government because it is fastgrowing and demands lower maintenance. According to local government, the land targeted for planting was on slopes where there is evidence of flooding or landslides, and areas considered unused. Annual inspections of township planting schemes are carried out by the county Forest Bureau, after which payments to household should be given. The County Forest Bureau noted a number of

\footnotetext{
${ }^{5} \mathrm{NVivo}$ software allows for the analysis of qualitative data by identifying common sequences, phrases, patterns and themes (c.f. Woodhouse et al., 2015).
} 
problems with the programme, including: livestock incursions in plantation areas, necessitating fencing at greater cost; the relatively low survival rate of saplings; and the greater level of care needed compared to other parts of China due to Daocheng's harsh climate.

More than half (twenty-eight out of fifty) of those interviewed in Samdo had planted trees on their own allocated land (used for agriculture and grazing), and according to local government figures, a total of $1,500 m u^{6}$ (100 hectares) has been planted in the township. ${ }^{7}$ Of the land that had been allocated to the fifty interviewed households (21.5 hectares), 3.9 hectares had been planted. Those who had participated had planted, on average, thirty-six per cent of their land (ranging from ten to one hundred per cent, i.e. retiring all of their available farm land). Many people had participated in communal planting on government land in April 2009, for which they received seventy yuan per day. The principle of volunteerism was followed to a large extent, in that people chose whether or not to participate in both planting on their own agricultural land and through communal efforts.

Nevertheless, participants were instructed by local government officials as to which trees to plant and where to plant them.

The greatest contributor to erosion, which the SLCP aims to reduce, is thought by the Chinese Government to be farming on steep slopes, so the programme is intended to target these and other unproductive areas for retirement (Liu et al., 2008). In Samdo, however, where cultivation is generally carried out in the valley floor, most plots on flat land next to farmland are still being cultivated or used for grazing by households. ${ }^{8}$ Some areas of afforestation on agricultural land were very small, not on sloping land, and had been fenced off to protect it from livestock. Although the local government had attempted to balance this with communal plantations on sloping mountain sides, there appeared to be a mistargeting of productive plots for conversion. Rather than slopes, flat land in the township that fell into the targeted area was accepted for retirement, and areas alongside the road were planted, probably to facilitate monitoring. There were visible areas where the tree planting had failed and trees had died. The local government planned to replace these trees but no further planting was planned beyond 2010. In key-informant interviews with local officials from the Forest Bureau of Daocheng County the programme was presented as a great success and was said to have 'restored' the land.

\footnotetext{
${ }^{6} \mathrm{Mu}$ is a Chinese unit of land measurement: one hectare equals fifteen $m u$.

${ }^{7}$ Figure provided by the Township government of Sangdui.

${ }^{8}$ Households have use-rights over areas of land. This began in the early 1980s with the introduction of the Household Responsibility System, which redistributed collective land and resources (e.g., livestock) to individual households.
} 


\section{Perceived impacts on material wellbeing}

Tree planting under the 'Grain for Green' scheme provoked a particular and consistent response in members of the community in Samdo. In response to open-ended questions about the impact of the programme, people did not generally frame this activity as the state does - as an initiative to restore the environment - but primarily in economic terms: thirty-six of the fifty households surveyed saw the primary positive benefit to be the cash payments. Others (ten out of fifty), mainly those who had not participated, saw no benefits at all, and only two households reported the environmental benefits of the scheme in terms of protection against soil erosion and flooding. Many people described the tree planting scheme as payment for relatively easy work - a purely economic transaction - but the act was generally not seen as meaningful in any other way.

More than half of people interviewed (twenty-eight out of fifty) had voluntarily joined the scheme due to the incentive of payments, showing the pull of cash income in an increasingly monetised Tibetan economy where consumer goods such as motorbikes, televisions and mobile phones are readily available. More importantly, cash is increasingly needed for rising post-primary education costs and healthcare bills (Fischer, 2008). Of those who had planted trees on their land, the SLCP subsidies were providing, on average, nine per cent of their cash income. For some households, payments were perceived to exceed opportunity costs in the short term, with the added benefit of freeing up labour for other sources of income. A greater proportion of poorer households were concerned about the impact of SLCP on their livelihoods (five out of eleven categorised as poor expressed concerns, as opposed to two out of thirteen in the wealthy category). Six of the poor households had chosen not to plant on their land at all, primarily because of livelihood concerns (i.e. not having enough land to feed children), combined with uncertainty and suspicion about the government's intention - the same reasons some middle and wealthy households chose not to participate. Poorer households tended to have smaller household sizes and therefore less labour capacity as well as smaller plots of land (Table 1). Concerns about the impacts on livelihoods, which sixteen of the fifty household respondents expressed, centred on not having sufficient land for growing food, or enough money after payments end to buy food: 
'It [SLCP] is good if you get enough money. But for this family, if we plant trees on the farm land, the children won't have enough to eat and we would not have enough money to buy food from the market.' [sixty-four-year-old man; agro-pastoralist; non-participant in SLCP]

Table 1: Characteristics of surveyed households in different wealth categories and opinions about SLCP

\begin{tabular}{|c|c|c|c|c|c|c|c|c|c|c|}
\hline \multirow[t]{2}{*}{$\begin{array}{l}\text { Wealth } \\
\text { category }\end{array}$} & \multirow[t]{2}{*}{$\begin{array}{l}\text { No. of } \\
\text { house- } \\
\text { holds }\end{array}$} & \multirow[t]{2}{*}{$\begin{array}{l}\text { Households } \\
\text { participating } \\
\text { in SLCP }\end{array}$} & \multirow[t]{2}{*}{$\begin{array}{l}\text { Mean } \\
\text { household } \\
\text { size }\end{array}$} & \multirow[t]{2}{*}{$\begin{array}{l}\text { Mean no. } \\
\text { of } \\
\text { livestock }\end{array}$} & \multirow[t]{2}{*}{$\begin{array}{l}\text { Mean } \\
\text { amount of } \\
\text { land (mu) }\end{array}$} & \multirow[t]{2}{*}{$\begin{array}{l}\% \\
\text { educated } *\end{array}$} & \multicolumn{2}{|c|}{$\begin{array}{l}\text { Positive } \\
\text { opinions about } \\
\text { SLCP }\end{array}$} & \multicolumn{2}{|c|}{$\begin{array}{l}\text { Negative opinions } \\
\text { about SLCP }\end{array}$} \\
\hline & & & & & & & money & other & livelihood & other \\
\hline Wealthy & 13 & 8 & 6.4 & 33.7 & 8.0 & 85 & 10 & 2 & 2 & 2 \\
\hline Medium & 26 & 15 & 6.0 & 27.2 & 6.7 & 42 & 21 & 1 & 9 & 3 \\
\hline Poor & 11 & 5 & 3.3 & 5.6 & 4.2 & 55 & 5 & 1 & 5 & 2 \\
\hline Total & 50 & 28 & 5.5 & 24.0 & 6.5 & 56 & 36 & 4 & 16 & 7 \\
\hline
\end{tabular}

*Households with one of more members over the age of 16 who have received any formal education

These concerns, however, were not restricted to poor households, and the poor households receiving subsidies certainly welcomed the cash boost. The common view was that the subsidies could help those with less livelihood security, especially those with fewer livestock:

'It [the SLCP] is especially good for people who don't have many livestock or when the harvest is not good and there is not a stable source of livelihood.' [forty-five-year-old man, agro-pastoralist, non-participant in SLCP] 
Indeed, eight of the ten households not raising livestock participated in planting trees on their farmland.

The SLCP is designed to induce structural change in the rural economy by incentivising the retirement of land and a movement to alternative employment options, as the over-supply of on-farm labour and the cultivation of marginal land are seen to be a driving force in rural poverty in China. This offers the best chance for the programme to meet its ambitious win-win aim for environment and poverty alleviation. A minority of households (fourteen out of fifty) had members with off-farm employment in nearby towns, as well as within Samdo itself. This work, however, was largely limited to construction work and other manual labour. More lucrative skilled labour and jobs in the service industry (e.g. mechanics, traders and veterinarians) were confined to middle-income and wealthy households who had more education. This reflects the broader trend of rural Tibetans being at a competitive disadvantage due to disparities in education and skills (Fischer, 2013). Eleven of these households were participating in SLCP, suggesting that the scheme was incentivising households to shift labour to off-farm employment. For the remaining seventeen households receiving SLCP subsidies, the barriers to accessing off-farm work were too great or the incentives not great enough (see also Grosjean and Kontoleon, 2009). In Samdo, poor households with little access to transport, social capital or education were constrained from accessing skilled work (four out of eleven were employed off-farm, but this was limited to menial construction labour). They also tended to receive fewer benefits from the thriving trade in caterpillar fungus due to limited labour capacity and trading networks, although all households are benefiting from the trade (Woodhouse et al., 2014). Ideas about future development in the local area centred on increasing access to caterpillar fungus (often deemed to be the 'the only way to get a high income here', as put by a fifty-eight year old male informant and agro-pastoralist), and ensuring the continuation of livestock and agricultural production, which were linked to historically-rooted Tibetan ideas of identity.

\section{Environmental sustainability issues}

There was disillusionment with the scheme at a practical level, and, echoing scientific research, local people questioned both the environmental benefits and the methods of implementation. Several residents reported that trees had died on their land, either since they had received the funds or before, in which case they did not receive full compensation. In the latter case, one respondent had reported 
that it had been too late to cultivate the land that year. There was a sense of absurdity about the planting scheme given the low survival rates and the apparent lack of accountability in the compensation process:

'There are no results - it's not good or bad. After the government people go, the trees die, and when they come back we plant more trees.' [thirty-year-old woman; agro-pastoralist; SLCP participant]

Low survival rates were considered by respondents to be the result of a combination of poor sites and minimal after-care, especially protection from livestock. Limited training on tree care (e.g. watering seedlings, protection from livestock) had reportedly been conducted, but government support for continuing maintenance was absent. Overall, badly-managed implementation meant that incentives for after-care were insufficient, and perceived corruption with respect to the local government's distribution funds within the scheme (voiced by two respondents) is unlikely to incentivise participants to look after the trees.

Beyond the eight years that the payments run, no further incentives for management and maintenance of the vegetation will be provided. This severely undermines the ecological sustainability of the programme, and there was a lack of certainty voiced in Samdo about who would be responsible for the trees in the future. These local problems reflect broader concerns about the lack of accountability and permanence of the scheme. Given that the majority of households had not shifted employment away from the land, and families will not see economic or social benefits from trees beyond the payment period, it is likely that at least some will return the land to cultivation and grazing. This outcome does not appear to be unusual: in one study in Shaanxi Province in Northern China, as many as one third of farmers reported that they planned to return to farming after SLCP payments end (Cao et al., 2009b).

\section{Local and contested meanings about land conversion}

Beyond these economic benefits and drawbacks, and the practical difficulties of ensuring tree survival, local people in Samdo also noted how the scheme relates to local meanings given to the 
environment, their livelihoods and their way of life. The dissonance between the SLCP and traditional agro-pastoralism was emphasised by some, especially older people. One man questioned the meaning of the project, since livelihoods and environmental protection had been compatible in the past:

'It [SLCP] is bad because Khampas ${ }^{9}$ need to eat butter and tsampa [barley meal]. It is meaningless...in the old times we were able to protect the trees, and have farms, and herd our cattle but we can't do all these things together any more.' [sixty-two-year-old man; agropastoralist; SLCP participant]

Here, the conflict with traditional livelihoods and lifestyles was elaborated by emphasising the integrated nature of everyday Tibetan life, and the contrast between the programme and an idealised history of agro-pastoralism, environmental protection and local autonomy. It also raises the question of how 'wasteland' or unproductive land - which is the focus of SLCP - is defined from different perspectives; what is considered unused by the state stood in stark contrast to local views of these same areas, which were actively used by livestock.

There was generally a lack of knowledge about the intention of the scheme, in contrast to the scientific rationales provided by some local people about the Natural Forest Protection Programme (Woodhouse, 2012) - which is essentially a ban on logging in the area. Some people expressed suspicions about the ultimate aim of the SLCP being the extraction of timber, for the state's benefit. This, and cynicism about the future of the policy, was grounded in historical experience of environmental policies. Older people in Samdo had seen large-scale, state-led logging between 1955 and 1980, as well as small-scale deforestation by local people during the political chaos and poverty of the Cultural Revolution (1966-1976). As one man summarised,

'The situation is very different now, the Chinese [government] came and people cut down the trees, and now they give us money to plant them!' [fifty-seven-year-old man; agropastoralist; participant in SLCP]

\footnotetext{
${ }^{9}$ Wylie transliteration: khams pa - the people of the Kham region of Tibet.
} 
The SLCP has the stated principle of volunteerism, which was associated with the failed massmobilisation campaigns of the Maoist era, and the unpaid labour on behalf of the state that characterised that period. At worst, the SLCP was seen as a continuation of the afforestation campaigns under Mao, in which an emphasis on quantity over quality resulted in a thirty per cent survival rate, despite claims of success (Smil, 1993: 59). Unlike some studies which suggest that participants had been coerced into involvement in the SLCP (Weyerhaeuser et al., 2005; He, 2014), this was not the case in Samdo, although there was little or no autonomy regarding locations and the tree species planted. As noted above, twenty-two of the fifty households surveyed had decided not to participate because of mistrust and concern about loss of productive land.

The scheme was not only linked to historical campaigns but wider state-controlled development efforts, and local perspectives must be viewed within this context:

'If the government plants on the mountains it is beneficial, but on the farmland and pastures it is bad as we need to plant crops and keep livestock. If they fence the grazing areas, the livestock cannot move and find more pasture ... if people plant on the farm, it cannot help the country. The farm becomes useless, and the trees die in the end. If you plant on the mountain, you can get money to buy salt and tea.' [seventy-year-old woman; agro-pastoralist; household participated in community tree planting]

This woman is referring not only to cultivation but the fact that grazing land (winter pastures in the village as well as mountainsides surrounding the valley) has been fenced. She also linked the 'Grain for Green' scheme to wider state-controlled development programmes which are transforming agropastoral systems, effectively reducing local control over the land and livelihoods. Most recently in Tibet, this includes tuimu huancao - converting pastures to grassland, and the related ecological resettlement programmes. At the time of research, this policy had not been implemented in Daocheng, but other pastoralist-focused projects were being implemented, including the building of brick homes in winter grazing areas, the building of pig pens as part of a rural development project, and the fencing of grazing areas, particularly along roads. Doubts about these policies were voiced in the community: for example, many people expressed their intention not to use the winter homes. 
A marked distinction emerged in discussions about tree planting carried out on mountain slopes, on government land, versus that on farmland or pasture. The few who spoke about the benefits of the scheme - beyond access to cash - cited the prevention of soil erosion and 'improved happiness', with specific reference to the planting on the mountain slopes carried out in a communal effort in 2007. In contrast, tree planting on agricultural fields and pastures was perceived negatively:

'It [the tree planting] is good on the mountains if the trees become forest - it makes the land joyful (sa-cha tsipo). ${ }^{10}$ Planting trees on the farm land is good for getting money, but not if the trees die as the land becomes useless.' [thirty-seven-year-old man; agro-pastoralist; nonparticipant in SLCP]

The trees planted under SLCP did not evoke non-monetary appreciation as natural forest did, or those trees planted on mountainsides that had the potential to become forest. Direct references to religious or cultural meaning in discussions regarding the SLCP were notable by their absence. This stands in sharp contrast with forest protection under the NFPP and laws on hunting wildlife, which were viewed through a religious framework and seen as a means of meeting religious obligations (Woodhouse, 2012). Protection of forest, facilitated in part through government rules on logging and firewood collection, and allowing the monastery authority over several sacred sites, were seen as a way of supporting relationships with autochthonous gods and spirits - the yul-lha-which are associated with non-extractive norms on certain mountains surrounding the valley. ${ }^{11}$

The implementation of SLCP represents the imposition of the recent Chinese state discourse of 'ecological construction' on the landscape as a means to support economic growth and ensure social stability. Central policies are conveyed to local governments as directives to implement. In this process, ecological construction was interpreted by local government officials as 'restoration', and emphasis was placed on increasing vegetation cover, and meeting or exceeding targets for number of trees planted, rather than targeting ecologically vulnerable areas. Although local Tibetans in Samdo recognised that deforestation had occurred in recent history, and saw the natural regeneration of trees as connected to karmic good and a positive sign of both environmental and community recovery, the idea of actively restoring forest did not appear in discussions in the same way. It did not seem possible from the local perspective to construct forest, especially on areas of land associated with livelihoods -

\footnotetext{
${ }^{10}$ Wylie transliteration: sa cha skyid po

${ }^{11}$ See Woodhouse et al. (2015) for discussion of the religious dimensions of environmental relationships in Samdo.
} 
the pastures and agricultural land. In fact, several people distinguished between the 'natural' (rang byung) and planted trees when discussing the landscape. The apparent and reported low survival rates under the SLCP only served to confirm these distinctions to local people.

\section{DISCUSSION}

The SLCP is one programme within a set of Chinese state policies which are transforming rural people's access to land and resources, their livelihoods, and the landscapes of which they have historically been a part. The policies are founded upon the premise that environmental restoration is dependent on shifting livelihoods away from agriculture and pastoralism, in an apparent win-win for the environment and poverty. As illustrated here, through the case study of the SLCP in a Tibetan rural community, the process has pronounced local economic effects, as well as cultural and political implications.

Overall, the legitimacy and sustainability of the programme is threatened by a mismatch between rhetoric and the experienced realities of people on the ground. The SLCP is certainly impressive in its scale and the speed with which it has been implemented. Using the narrow and short-term criteria of participation and increase in vegetative cover, the programme can be viewed as an overall success (Liu et al., 2008). However, although many people in Samdo viewed the primary benefit to be the income they received from the scheme, there was visible evidence of poor sapling survival, and some people, especially poorer households, expressed concerns about the programme conflicting with livelihoods through the retirement of agricultural and grazing land in the valley. Research suggests that there are variations across communities with respect to the economic impacts of the SLCP, including improvements in income (Lin and Yao, 2014; Yin et al., 2014) and decreases in income inequality (Li et al., 2011) as well as reduced income (Liang et al., 2012). Overall, it appears that impacts are dependent on local economic conditions and institutional structures (Yao et al., 2010; He, 2014). Actual economic changes, which are positive for at least some households in Samdo, may not align exactly with subjective experiences (Wang and McClaren, 2012), but the latter remain important for participation, sustainability of the program and experienced wellbeing. The apparent variation in benefits along wealth lines in Samdo parallels research which shows that poorer households are less able to cope with changes, having fewer livelihoods choices and more insecure income (Ma et al., 2009; Wang and McClaren, 2012). The flat-rate compensation does not account for inter-household 
production variability, and the consequent differing opportunity-costs potentially affecting distributional justice outcomes.

Given the finite nature of the payments, to meet the win-win objectives of poverty alleviation and environmental restoration, the programme needs to be complemented by structural economic change. In Samdo, a minority of households were engaged in off-farm work, but this was not combined with a desire (or even an ability) to reduce or abandon subsistence livelihoods, and was largely confined to sectors such as construction that pay poorly. Far from moving off the land, people are committed to the caterpillar fungus trade, which reduces their dependence on undesirable menial-wage employment and is intertwined with the pastoral lifestyle, although the income it brings may be impacting livelihood decisions, such as herd composition, in certain Tibetan areas (Sulek, 2010). The amounts received in SLCP subsidies pale in comparison to earnings from caterpillar fungus which provide, on average, seventy-two per cent of household income (Woodhouse et al., 2014). Those focused on livestock raising were more likely to have made the decision not to plant trees on their land, suggesting that pastoralists are focused on retaining their household asset base (and, indeed, owning livestock, alongside other assets, was one local measure of wealth). Tibetans tend to use subsistence occupations as a livelihood base for coping with uncertainty, and as a basis for engaging in labour markets on their own terms, in preference to menial-labour jobs which do not align with cultural norms regarding dignity (Fischer, 2008). There was certainly some investment in off-farm work, which reflects the Tibetan economy's overall transformation away from the primary sector towards construction and service industries in response to policies of this type (Fischer, 2011). The SLCP and tuimi huancao go hand-in-hand with the more radical push towards urbanisation through the 'ecological migration' policy, which also employs financial incentives. There is evidence, however, that Tibetans face many challenges in shifting their livelihoods away from pastoralism and settling in urban areas, including social disruption, reduced livelihood security and lack of employment (Du, 2012; Tashi and Foggin, 2012). At least in the case of the SLCP, there is the option to reconvert land back to agriculture or pasture. But the question remains as to the future of pastoralist and agropastoralist livelihoods in western China, given the pressures facing rural people. To a large extent, the caterpillar fungus trade allows a continuation of rural life in places like Samdo, although the heavy reliance on this trade means that any future collapse in the market could be disastrous for rural livelihoods. More broadly, Fischer (2013) argues that development in Tibet and the structural shift away from the primary sector - driven by government policy and subsidies - are based on a disempowerment model, which, despite improvements in overall material wealth, results in the marginalisation of Tibetans and reinforcement of cultural biases, resulting in even greater inequalities. 
These cultural and linguistic biases are illustrated by the divergence between state environmental discourses and local understandings. Government policy does not consider the non-economic values and benefits associated with retaining a rural subsistence lifestyle, and the associated rights to historically-held agricultural and pastoral land; instead, the government assumes a rationalist view of how people weigh their interests. The case study illustrates how the Chinese state values and metaphors for nature - as a service provider, and natural capital which can be constructed - contrast with local Tibetan perspectives, undermining the possibilities for environmental improvements at a local level. The environmental-degradation narrative justifies policies applied not only to grasslands, but also forests, as a basis for 'modernising' rural livelihoods and pushing urbanisation. Areas viewed as degraded or 'wasteland' by the state are not viewed as such locally. Indeed, evidence of the scale of and reasons for grassland degradation, upon which policies of ecological migration are based, is lacking (Harris, 2010). Although there is evidence of extensive deforestation in western China in the twentieth century, the mistargeting of land, poor sapling survival and the fragmentation of small plots amidst pasture or cultivated land in Samdo will reduce the positive ecological impact. This parallels research which suggests that the potential ecological and biodiversity benefits are not being realised (Viña et al., 2013), and in some areas, lack of attention to local conditions can, in fact, have negative impacts on diversity, water availability and vegetation (Cao et al., 2009a; Cao et al., 2011).

The contrast between the approach of 'ecological construction' used by the Chinese state and local ideas of nature is highlighted in the distinction made by local people between planted and natural forest. Beyond the subsidies it generated, the former did not have value, particularly on previously productive land. The fact that people were much more positive about plantations on state-held mountainsides not being used for grazing only serves to highlight this divergence in ideas. The government discourse attempts to legitimise these interventions, but despite their lack of political agency, Tibetans were contesting these ideas and were fully cognisant of the parallels with failed previous environmental management campaigns, as well as the broader efforts to enact control over natural resources. The dissonance between government discourse and local ideas highlights the importance of cultural recognition when considering justice within environmental programmes (Sikor et al., 2014). There is a need to move beyond the concerns about payments' efficiency and technical details, towards considering how intervention processes can acknowledge the distinct identities, histories and visions of nature held by local people. This is particularly pertinent where power asymmetries already exist between the Chinese authorities and local communities, especially in ethnic-minority rural areas, which overlap considerably with the rangelands of western China where these policies are being implemented. Indeed, this lack of recognition, political exclusion and the structural inequalities created by development policies help explain the politics of protest in Tibet as well as the revival of Tibetan culture (Fischer, 2012). 
As a state-run rather than purely market-driven enterprise, the SLCP deviates from conceptions of neo-liberal conservation in some respects, resulting in no real shift in power, but rather expropriating control over resources. It is similar, however, in using an economic valuation of the natural environment which paves the way for commodification, a process that involves monetisation and appropriation (Gómez-Baggethun and Ruiz-Perez, 2011). Critics have presented ethical reasons for contesting commodification (e.g. McCauley, 2006), but it may also result in counter-productive impacts on the material environment. An emphasis on financial valuation has been shown to undermine other forms of value which are not amenable to pricing but serve to cultivate conservation sentiments (Bowles, 2008; Vatn, 2010). There is a risk that programmes like SLCP will undermine non-economic incentives for stewarding the environment, of which there are several dimensions in Tibet, centred on customary management systems and Tibetans' cosmological beliefs.

Commodification has occurred through the mobilisation of paid labour to plant what are largely monocultures on agricultural and pastoral land, which abstracts the trees (and the meaning they may otherwise hold) from their social and ecological contexts. External interventions related to 'ecological construction' are decoupling rather than reconnecting pastoral and agro-pastoral society from the supporting ecological system, ultimately impacting sustainability and resilience ( $\mathrm{Li}$ and $\mathrm{Li}, 2012$ ). For example, SLCP has been shown to have reduced the swidden agricultural systems and related crop diversity of the Dulong People of Yunnan Province, which is central to their livelihoods and culture (Shen et al., 2010).

With a focus on local perspectives, this case study illustrates the problems faced by rural communities in China, with policies like 'ecological restoration' that are centred on technical solutions, top-down approaches and monetary incentives and subsidies. By expropriating land and resources through the physical relocation of people, these policies undermine the long-term continuity of rural livelihoods especially those centred on pastoralism - to which many Tibetans remain rooted. The minority nationalities targeted by such policies have fewer resources to cope with these changes and wield less political power with which to contest processes. The increased interest of the Chinese government in commodity and pricing approaches only reflects wider global socio-political trends in which economic rationality is expanded into ecosystems. But the particularities of the situation - the topdown approach and power differentials between the state and local communities - make it of particular concern. The policy rhetoric promises a simple solution to the complex problems of ecological sustainability and economic poverty. As shown by the increases in vegetation cover, the approach can succeed in the short-term as a tool for environmental improvement if viewed in one dimension, but the lack of consideration for broader concepts of human well-being, cultural and livelihood viability, equity and participation, as well as ecological sustainability, is unlikely to result in - despite promises of - a long-term win-win outcome. 


\section{REFERENCES}

Bennett, M. 2008. 'China's sloping land conversion program: Institutional innovation or business as usual?' Ecological Economics 65(4): 699-711. http://dx.doi.org/10.1016/j.ecolecon.2007.09.017

Bowles, S. 2008. 'Policies designed for self-interested citizens may undermine the moral sentiments: evidence from economic experiments'. Science 320(5883): 1605-1609.

http://dx.doi.org/10.1126/science.1152110

Buscher, B. 2012. 'Payment for ecosystem services as neoliberal conservation: (Reinterpreting) evidence from the Maloti-Drakensberg, South Africa'. Conservation and Society 10: 29-41. http://dx.doi.org/10.4103/0972-4923.92190

Cao, S., L. Chen and X. Yu. 2009a. 'Impact of China's Grain for Green Project on the landscape of vulnerable arid and semi-arid agricultural regions: a case study in northern Shaanxi Province'. Journal of Applied Ecology 46(3): 536-543. http://dx.doi.org/10.1111/j.1365-2664.2008.01605.x

Cao, S., C. Xu, L. Chen and X. Wang. 2009b. 'Attitudes of farmers in China's northern Shaanxi Province towards the land-use changes required under the Grain for Green Project, and implications for the project's success'. Land Use Policy 26(4): 1182-1194. http://dx.doi.org/10.1016/j.landusepol.2009.02.006

Cao, S. 2011. 'Impact of China's large-scale ecological restoration program on the environment and society in arid and semiarid areas of China: achievements, problems, synthesis, and applications'. Critical Reviews in Environmental Science and Technology 41(4): 317-335.

http://dx.doi.org/10.1080/10643380902800034

Conservation International. 2012. Biodiversity Hotspots: Mountains of Southwest China. Accessible online at http://www.conservation.org/where/priority areas/hotspots/asia-pacific/Mountains-ofSouthwest-China/Pages/default.aspx (accessed 8 July 2015).

Corbera, E., K. Brown and W. Adger. 2007. 'The equity and legitimacy of markets for ecosystem services'. Development and Change 38: 587-613. http://dx.doi.org/10.1111/j.14677660.2007.00425.x

Du, F. 2012. 'Ecological resettlement of Tibetan herders in the Sanjiangyuan: a case study in Madoi County of Qinghai'. Nomadic Peoples 16: 116-133. http://dx.doi.org/10.3167/np.2012.160109 
Fischer, A. 2008. 'Subsistence and rural livelihood strategies in Tibet-under rapid economic and social transition'. International Association of Tibetan Studies Journal 4: 41-49.

Fischer, A. 2011. 'The great transformation of Tibet? Rapid labour transitions in times of rapid growth in the Tibetan Autonomous Region'. Himalaya 30: 63-78.

Fischer, A. 2012. 'The Geopolitics of Politico-Religious Protest in Eastern Tibet'. Cultural Anthropology, Hot Spot Forum Online 4: 1-6.

Fischer, A. 2013. The Disempowered Development of Tibet: A Study in the Economics of Marginalization. Lanham, MD: Lexington Books.

Gómez-Baggethun, E. and M. Ruiz-Pérez. 2011. 'Economic valuation and the commodification of ecosystem services'. Progress in Physical Geography 35: 613-628.

http://dx.doi.org/10.1177/0309133311421708

Grosjean, P. and A. Kontoleon. 2009. 'How sustainable are sustainable development programs? The case of the Sloping Land Conversion Program in China'. World Development 37(1): 268-285. http://dx.doi.org/10.1016/j.worlddev.2008.05.003

Harris, R. 2010. 'Rangeland degradation on the Qinghai-Tibetan Plateau: a review of the evidence of its magnitude and causes'. Journal of Arid Environments 74: 1-12.

http://dx.doi.org/10.1016/j.jaridenv.2009.06.014

Harkness, J. 1998. 'Recent trends in forestry and conservation of biodiversity in China'. China Quarterly 156: 911-934. http://dx.doi.org/10.1017/S0305741000051390

He, J. 2014. 'Governing forest restoration: local case studies of sloping land conversion program in Southwest China'. Forest Policy and Economics 46: 30-38.

http://dx.doi.org/10.1016/j.forpol.2014.05.004

Jiang, H. 2006. 'Decentralization, ecological construction, and the environment in post-reform China: case study from Uxin Banner, Inner Mongolia'. World Development 34: 1907-1921. http://dx.doi.org/10.1016/j.worlddev.2005.11.022

Li, W. 1993. Forests of the Himalayan-Hengduan Mountains of China and Strategies for their Sustainable Development. Kathmandu: International Centre for Integrated Mountain Development [ICIMOD]. 
Li J., M. Feldman, S. Li and G. Daily. 2011. 'Rural household income and inequality under the Sloping Land Conversion Program'. PNAS 108: 7721-7726.

http://dx.doi.org/10.1073/pnas.1101018108

Li, W. and Y. Li. 2012. 'Managing rangeland as a complex system: how government interventions decouple social systems from ecological systems'. Ecology and Society 17(1): 9.

http://dx.doi.org/10.5751/ES-04531-170109

Liang, Y., S. Li, M. Feldman and G. Daily. 2012. 'Does household composition matter? The impact of the Grain for Green Program on rural livelihoods in China'. Ecological Economics 75: 152-160. http://dx.doi.org/10.1016/j.ecolecon.2012.01.019

Lin, Y. and S. Yao. 2014. 'Impacts of the sloping land conversion program on rural household income: an integrated estimation'. Land Use Policy 40: 56-63.

http://dx.doi.org/10.1016/j.landusepol.2013.09.005

Liu, J., S. Li, Z. Ouyang, C. Tam and X. Chen. 2008. 'Ecological and socioeconomic effects of China's policies for ecosystem services'. PNAS 105: 9477-9482.

http://dx.doi.org/10.1073/pnas.0706436105

Ma, H., Y. Lu, Y. Xing, G. He and Y. Sun. 2009. 'Rural households' attitudes and economic strategies toward conversion of cropland'. Environmental Management 43: 1039-1047.

http://dx.doi.org/10.1007/s00267-009-9290-Z

McCauley, D. 2006. 'Selling out on nature'. Nature 443(7107): 27-28.

http://dx.doi.org/10.1038/443027a

McNally, C. 2004. 'Sichuan: driving capitalist development westward'. The China Quarterly 178: 426-447. http://dx.doi.org/10.1017/S0305741004000244

Mills, M. 2003. Identity, Ritual and State in Tibetan Buddhism: the Foundations of Authority in Gelukpa Monasticism. London: Routledge.

QSR International. 2010. NVivo (Version 9). QSR International Pty Ltd.

Shapiro, J. 2001. Mao's War against Nature: Politics and the Environment in Revolutionary China. Cambridge: Cambridge University Press. http://dx.doi.org/10.1017/CBO9780511512063 
Shen, S., A. Wilkes, J. Qian, L. Yin, J. Ren and F. Zhang. 2010. 'Agrobiodiversity and biocultural heritage in the Dulong Valley, China'. Mountain Research and Development 30: 205-211. http://dx.doi.org/10.1659/MRD-JOURNAL-D-09-00085.1

Sikor, T., A. Martin, J. Fisher and J. He. 2014. 'Toward an empirical analysis of justice in ecosystem governance.' Conservation Letters 7: 524-532. http://dx.doi.org/10.1111/conl.12142

Smil, V. 1993. China's Environmental Crisis: An Inquiry into the Limits of National Development. Armonk, NY: M.E. Sharpe.

Sulek, E. 2010. 'Disappearing sheep: the unexpected consequences of the emergence of the caterpillar fungus economy in Golok, Qinghai, China'. Himalaya 30: 9-22.

Tashi, G. and M. Foggin. 2012. 'Resettlement as development and progress? Eight years on: a review of emerging social and development impacts of an 'ecological resettlement' project in Tibet Autonomous Region, China'. Nomadic Peoples 16: 134-151. http://dx.doi.org/10.3167/np.2012.160110

Vatn, A. 2010. 'An institutional analysis of payment for environmental services'. Ecological Economics 69: 1245-1252. http://dx.doi.org/10.1016/j.ecolecon.2009.11.018

Viña, A., C. Xiaodong, W. Yang, W. Liu, Y. Li, Z. Ouyang and J. Liu. 2013. 'Improving the efficiency of conservation policies with the use of surrogates derived from remotely sensed and ancillary data'. Ecological Indicators 26: 103-111. http://dx.doi.org/10.1016/j.ecolind.2012.10.020

Wang, S., G. Cornelis van Kooten and B. Wilson. 2004. 'Mosaic of reform: forest policy in post-1978 China'. Forest Policy and Economics 6: 71-83. http://dx.doi.org/10.1016/S1389-9341(02)00078-3

Wang, C. and V. McClaren. 2012. 'Evaluation of economic and social impacts of the sloping land conversion program: a case study in Dunhua County, China.' Forest Policy \& Economics 14: 50-57. http://dx.doi.org/10.1016/j.forpol.2011.06.002

Weyerhaeuser, H., A. Wilkes and F. Kahrl. 2005. 'Local impacts and responses to regional forest conservation and rehabilitation programs in China's northwestern Yunnan Province'. Agricultural Systems 85: 234-253. http://dx.doi.org/10.1016/j.agsy.2005.06.008

Winkler, D. 2003. 'Forest use and implications of the 1998 logging ban in the Tibetan Prefectures of Sichuan: case study on forestry, reforestation and NTFP in Litang County, Ganzi TAP, China'. Informatore Botanico Italiano 35: 116-125. 
Winkler, D. 2008. 'Yartsa Gunbu (Cordyceps sinensis) and the fungal commodification of Tibet's rural economy'. Economic Botany 62(3): 291-305. http://dx.doi.org/10.1007/s12231-008-9038-3

Woodhouse, E. 2012. The Role of Tibetan Buddhism in Environmental Conservation under Changing Socio-Economic Conditions in China. PhD thesis, Imperial College London.

Woodhouse, E., P. McGowan and E. Milner-Gulland. 2014. 'Fungal gold and firewood on the Tibetan plateau: examining access to diverse ecosystem provisioning services within a rural community'. Oryx 42(1): 30-38. http://dx.doi.org/10.1017/S0030605312001330

Woodhouse, E., M. Mills, P. McGowan and E. Milner-Gulland. 2015. 'Religious relationships with the environment in a Tibetan rural community: interactions and contrasts with popular notions of indigenous environmentalism'. Human Ecology 43: 295-307. http://dx.doi.org/10.1007/s10745-015$\underline{9742-4}$

Wunder, S., S. Engel and S. Pagiola. 2008. 'Taking stock: a comparative analysis of payments for environmental services programs in developed and developing countries'. Ecological Economics 65: 834-852. http://dx.doi.org/10.1016/j.ecolecon.2008.03.010

Xu, J. and J. Ribot. 2004. 'Decentralisation and accountability in forest management: a case from Yunnan, Southwest China'. The European Journal of Development Research 16(1): 153-173. http://dx.doi.org/10.1080/09578810410001688789

Yao, S., Y. Guo and X. Huo. 2010. 'An empirical analysis of the effects of China's land conversion program on farmers' income growth and labour transfer'. Environmental Management 45: 502-512. http://dx.doi.org/10.1007/s00267-009-9376-7

Yeh, E. 2005. 'Green governmentality and pastoralism in Western China: converting pastures to grasslands'. Nomadic Peoples 9: 9-30. http://dx.doi.org/10.3167/082279405781826164

Yeh, E. 2013. 'The politics of conservation in rural China'. The Journal of Peasant Studies 40: 11651188. http://dx.doi.org/10.1080/03066150.2013.859575

Yeh, E. 2014. 'Reverse environmentalism: contemporary articulations of Tibetan Buddhism, culture, and environmental protection', in J. Miller, D. Yu and P. Van der Veer (eds), Religious Diversity and Ecological Sustainability in China, pp. 194-219. London: Routledge.

Yin, R., C. Liu, M. Zhao, S. Yao and H. Liu. 2004. 'The implementation and impacts of China's largest payment for ecosystem services program as revealed by longitudinal household data'. Land Use Policy 40: 45-55. http://dx.doi.org/10.1016/j.landusepol.2014.03.002 